Parnell, J., Boyce, A.J., Osinski, G.R., Matthew, R.M., Izawa, M.R.M., Banerjee, N., Flemming, R., and Lee, P. (2012) Evidence for life in the isotopic analysis of surface sulphates in the Haughton impact structure, and potential applications on Mars. International Journal of Astrobiology, 11 . pp. 93-101. ISSN 1473-5504

Copyright (C) 2012 Cambridge University Press

A copy can be downloaded for personal non-commercial research or study, without prior permission or charge

The content must not be changed in any way or reproduced in any format or medium without the formal permission of the copyright holder(s)

When referring to this work, full bibliographic details must be given

http://eprints.gla.ac.uk/67497/

Deposited on: 4 June 2013

Enlighten - Research publications by members of the University of Glasgow http://eprints.gla.ac.uk 


\title{
Evidence for life in the isotopic analysis of surface sulphates in the Haughton impact structure, and potential application on Mars
}

\author{
John Parnell', Adrian J. Boyce ${ }^{2}$, Gordon R. Osinski ${ }^{3}$, Matthew R.M. Izawa ${ }^{3}$, \\ Neil Banerjee ${ }^{3}$, Roberta Flemming ${ }^{3}$ and Pascal Lee ${ }^{4}$ \\ ${ }^{1}$ Department of Geology and Petroleum Geology, University of Aberdeen, Aberdeen, UK \\ e-mail: J.Parnell@abdn.ac.uk \\ ${ }^{2}$ Scottish Universities Environmental Research Centre, Glasgow, UK \\ ${ }^{3}$ University of Western Ontario, London, Ontario, Canada \\ ${ }^{4}$ NASA Ames Research Center, Moffett Field, CA, USA
}

\begin{abstract}
The analysis of sulphur isotopic compositions in three sets of surface sulphate samples from the soil zone in the Haughton impact structure shows that they are distinct. They include surface gypsum crusts remobilized from the pre-impact gypsum bedrock (mean $\delta^{34} \mathrm{~S}+31 \%$ ), efflorescent copiapite and fibroferrite associated with hydrothermal marcasite (mean $\delta^{34} \mathrm{~S}-37 \%$ ), and gypsum-iron oxide crusts representing weathering of pyritic crater-fill sediments (mean $\delta^{34} \mathrm{~S}+7 \%$ ). Their different compositions reflect different histories of sulphur cycling. Two of the three sulphates have isotopically light (low $\delta^{34} \mathrm{~S}$ ) compositions compared with the gypsum bedrock (mean $\delta^{34} \mathrm{~S}+31 \%$ ), reflecting derivation by weathering of sulphides (three sets of pyrite/marcasite samples with mean $\delta^{34} \mathrm{~S}$ of $-41,-20$ and $-8 \%$ ), which had in turn been precipitated by microbial sulphate reduction. Thus, even in the absence of the parent sulphides due to surface oxidation, evidence of life would be preserved. This indicates that on Mars, where surface oxidation may rule out sampling of sulphides during robotic exploration, but where sulphates are widespread, sulphur isotope analysis is a valuable tool that could be sensitive to any near-surface microbial activity. Other causes of sulphur isotopic fractionation on the surface of Mars are feasible, but any anomalous fractionation would indicate the desirability of further analysis.

Received 14 April 2011, accepted 5 December 2011, first published online 9 January 2012
\end{abstract}

Key words: evidence for life, impact craters, Mars, sulphides, sulphur isotope fractionation.

\section{Introduction}

The search for evidence of life is a major goal of the exploration of Mars. Diverse types of evidence may be sought, but the most likely to be obtained will be some type of chemical signature. Data from terrestrial systems suggest that isotopic fractionation can provide rigorous evidence for biological activity. Consequently, isotopic analysis has been proposed as an important tool in the search for life (Space Studies Board 2007; van Zuilen 2008). One of the isotopic systems that could be interrogated during a remote mission is sulphur. On Earth, numerous studies have identified biological activity on the basis of strong fractionation between sulphate and sulphide (either directly measured or inferred from anomalously light compositions of sulphide), especially where seawater sulphate is transformed by microbial sulphate reduction into sulphide minerals with substantial accompanying isotopic fractionation (Machel 2001; Brunner \& Bernasconi 2005; Johnston et al. 2008). However, making such measurements depends upon sampling both parent sulphate and product sulphide, which may be unrealistic during Martian sampling campaigns in the foreseeable future. Sulphides on Mars, which are predicted to be widespread (Burns \& Fisher
1990, 1993), and are evident in Martian meteorites (Lorand et al. 2005), are very probably oxidized within accessible range of the surface (Chevrier et al. 2004; Lefticariu et al. 2006). Realistically, sampling is therefore limited to the sulphates.

Sulphates are widespread on the Martian surface, evident from both landers and remote sensing (Gendrin et al. 2005; Yen et al. 2008). Recent robotic missions on the surface have detected sulphates at Meridiani Planum (McLennan et al. 2005), Gusev Crater (Lane et al. 2008) and the Phoenix Lander site (Kounaves et al. 2010). It is likely that this ultimately reflects degassing, vapour-atmosphere interactions and chemical weathering of sulphur species from magmas that are much richer in sulphur than the terrestrial equivalents (Johnson et al. 2008; Gaillard \& Scaillet 2009; Righter et al. 2009). The sulphur has subsequently been processed in a wide variety of ways, including precipitation from hot springs, circulation in impact-driven hydrothermal systems, evaporative precipitation from groundwaters and sedimentary transport (King et al. 2004; King \& McLennan 2010). Hence, a range of sulphur-bearing mineral phases occurs in the Martian crust, and their diverse histories could have resulted in varying isotopic fractionation. 
Sulphates on Earth consistently record biosignatures of life in the ambient environment, hence the occurrences on Mars have led to repeated suggestions to analyse Martian sulphates in the search for evidence of life (Rothschild 1990; Cid \& Casanova 2001; Parnell et al. 2004; Aubrey et al. 2006). Most of this thinking has been focused on seeking molecular biosignatures (i.e. organic compounds). However, there is also potential to seek isotopic signatures in sulphate minerals, and instrumentation is being developed accordingly (Christensen et al. 2007; Franz et al. 2007, 2011). Biologically induced isotopic fractionation has been inferred in some studies of terrestrial sulphates (Toran \& Harris 1989; Glynn et al. 2006). In this study, we demonstrate that a similar approach is feasible during a robotic mission in a Mars analogue site.

\section{Analogue case study in Haughton impact structure}

We show here that a programme of sampling sulphates at the surface can yield isotope evidence of biological activity. We demonstrate this using samples from a transect through an impact crater, the Haughton impact structure on Devon Island, Canadian High Arctic. The Haughton impact structure was formed by a $39 \mathrm{Ma}$ (Cenozoic) impact (Sherlock et al. 2005), producing a $23 \mathrm{~km}$ diameter crater in bedrock that included $470 \mathrm{Ma}$ (Ordovician) beds of the sulphate mineral anhydrite (Osinski et al. 2005b). The Haughton impact caused extensive processing of sulphate-bearing and limestone bedrock. Impact breccias infilling the crater contains finely comminuted anhydrite and gypsum, composing up to $9 \%$ of the breccias, which are otherwise carbonate-rich (Osinski et al. 2005b). The sulphates are shocked to varying degrees, and have partially melted to form a groundmass to the breccias (Osinski et al. 2005b). The impact breccias cover an area of $\sim 54 \mathrm{~km}^{2}$, originally $>200 \mathrm{~m}$ thick (Osinski et al. 2005b). The crater was later (Eocene-Miocene) filled with fluvial-lacustrine sediment (Hickey et al. 1988; Osinski \& Lee 2005). The groundwaters in the impact structure are sulphate-rich (Lim \& Douglas 2003), reflecting interaction with the anhydrite beds in the Ordovician bedrock, and detritus derived from the bedrock.

The impact breccias are pervasively mineralized by pyrite, and locally by marcasite and selenite (gypsum). These sulphurbearing phases are all interpreted as products of hydrothermal activity induced by the residual heat of the impact event (Osinski et al. 2001, 2005a, b). Furthermore, we have shown in an earlier paper that the sulphides (pyrite and marcasite) have sulphur isotope compositions that indicate an origin through microbial sulphate reduction, which occurred as the impact structure cooled down (Parnell et al. 2010). The sulphidebearing deposits have experienced some oxidative weathering back to sulphates, including jarosite (Parnell et al. 2010). We show here that evidence of life can be sought in the sulphur isotopic composition of sulphates, as opposed to the sulphides reported previously, and thus makes the use of sulphur isotopic analysis on Mars a more realistic proposition.

The Haughton structure is appropriate as a test site for sulphur isotope investigations on Mars. In addition to the occurrence of surface sulphate deposits, the scale of the impact structure is comparable with many craters on Mars (Barlow
1990). An interpretation of sulphur isotope data from the Martian meteorite ALH84001 suggests cycling of sulphur through an impact-driven hydrothermal system (Greenwood et al. 2000a) such as is known to have occurred in the Haughton impact structure. The structure provides data for simulated rover field testing (Newsom et al. 2009): The sulphur isotope data reported here are interpreted as if they were recorded during a rover traverse of the crater. The Haughton impact structure is also used for testing of diverse other aspects of Martian and lunar exploration (e.g. Crucian et al. 2007; Furgale et al. 2010).

\section{Materials and methods}

\section{Sampling in Haughton impact structure}

In order to simulate robotic sampling, a series of sulphate and sulphide samples were collected on a single traverse through the Haughton Crater, at accessible points located along natural thoroughfares (Fig. 1). The traverse was made by joining two routes regularly used by all terrain vehicles from the Haughton Mars Project base camp (Fig. 1). At each location, the sampled phases are visible at a distance of at least $1 \mathrm{~m}$, and could therefore be readily sampled and visible to a robotic vehicle. In most cases, they are evidently a chemical precipitate (conspicuously crystalline and/or with a white/colourless hue). The dataset of 62 analyses includes 14 measurements reported by Parnell et al. (2010).

A total of ten sampling stations were selected. Progressing westwards through the crater, they are distinguished as follows: A. Surface crust of gypsum, which has clearly crystallized at the surface. Occurs above bedded gypsum as in D.

B. Iron sulphide (marcasite) veins up to centimetres width, particularly lining vuggy cavities in the impact breccias.

C. Surface efflorescent sulphate precipitates (predominantly copiapite $(\mathrm{Fe}, \mathrm{Mg}) \mathrm{Fe}_{4}\left(\mathrm{SO}_{4}\right)_{6}(\mathrm{OH})_{2} \bullet 20 \mathrm{H}_{2} \mathrm{O}$ and fibroferrite $\left.\mathrm{Fe}\left(\mathrm{SO}_{4}\right)(\mathrm{OH}) \bullet 5 \mathrm{H}_{2} \mathrm{O}\right)$ spatially associated with iron sulphides (B) and probably weathered from them.

D. Bedded gypsum rock below the impact breccias, evidently part of the pre-impact succession.

E. Pyrite-rich impact breccia, evident by ferruginous (rusty) weathering.

F. Selenite (gypsum) veins up to centimetres width, cutting the impact breccias, coarsely crystalline and discordant.

G. Clasts of gypsum up to $5 \mathrm{~cm}$ size in the impact breccias, conspicuous because of white colour.

H. Gypsum veinrock, cutting bedded sediment below the impact breccias. Part of the plumbing system below an impact-related hydrothermal vent.

I. Black, platy masses and centimetre-scale of pyritic sandstone. Lag deposit eroded and concentrated from crater-fill sediments.

J. Mixed gypsum-iron oxide crust above crater-fill sediments, at least some of which probably represents weathering of sulphide-bearing crater-fill sediments.

Sample types B, D and E were the subject of an earlier study (Parnell et al. 2010). The other seven sample types are new to 


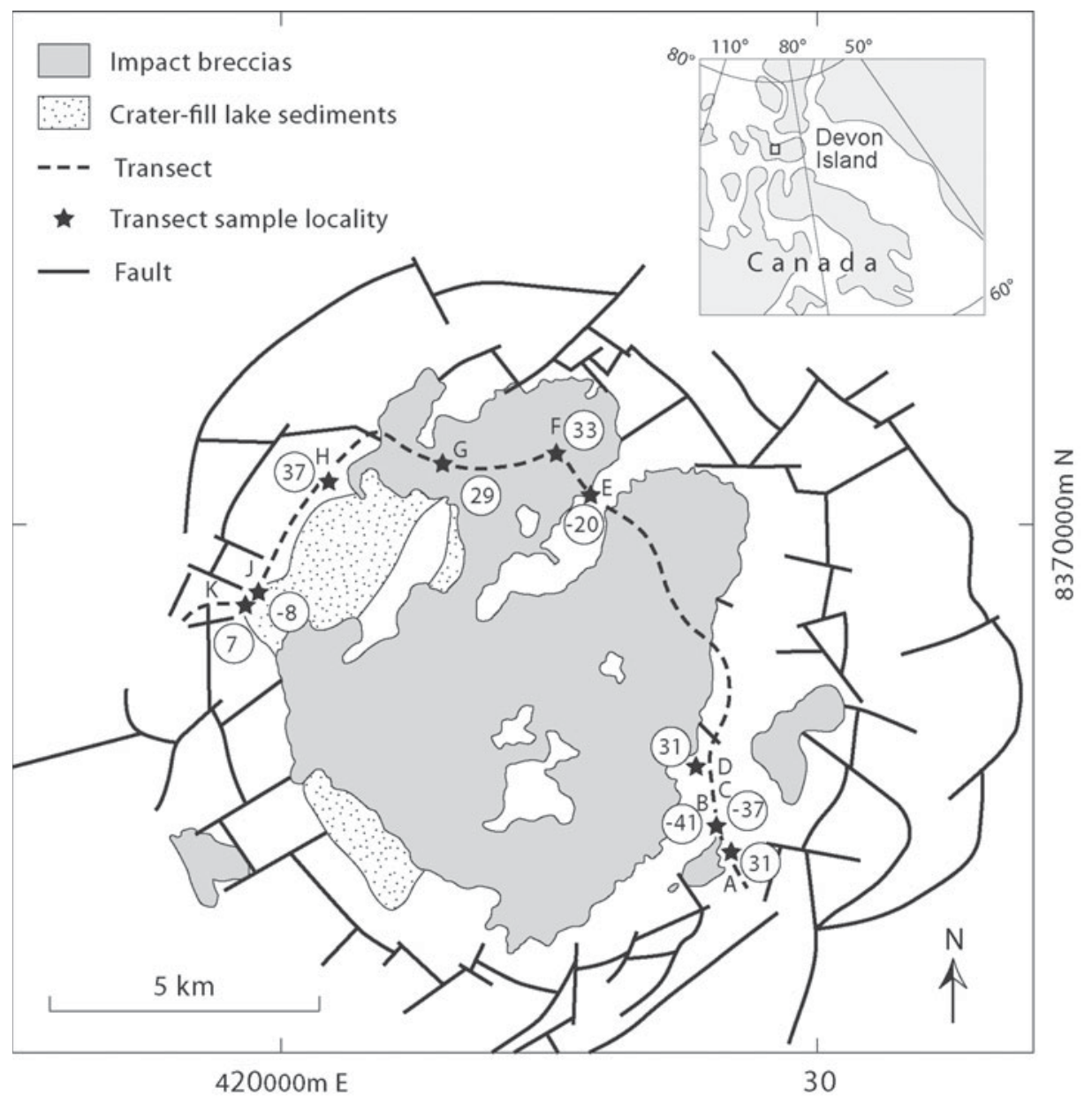

Fig. 1. Outline map of Haughton impact structure, showing distribution of impact breccias (after Osinski et al. 2005b), and sampling traverse with mean sulphur isotope compositions $\left(\delta^{34} \mathrm{~S} \% \mathrm{CDT}\right)$. Details of sampling stations are given in text.

this study. Images of several of the sampling stations are shown in Fig. 2. Samples were collected in polythene bags, and sub-sampled after laboratory determination of their mineralogy.

\section{Isotopic analysis}

Sulphate and sulphide samples were prepared for conventional sulphur isotopic analysis by heavy liquid and hand picking techniques. Heavy liquid separations were undertaken using suspension in bromoform. Sulphide and sulphate separates were then analysed by standard techniques (Robinson \& Kusakabe 1975; Coleman \& Moore 1978). In both cases, around $5-10 \mathrm{mg}$ was utilized for isotopic analysis. Minor contamination by non-S-bearing phases was tolerated, and has no effect on the final data. For sulphide analysis, $\mathrm{SO}_{2}$ gas was liberated by combusting the sulphides with excess $\mathrm{Cu}_{2} \mathrm{O}$ at $1075^{\circ} \mathrm{C}$, in vacuo. Sulphate analyses were performed by the technique of Coleman \& Moore (1978), in which $\mathrm{SO}_{2}$ gas is liberated by combustion with excess $\mathrm{Cu}_{2} \mathrm{O}$ and silica, at $1125^{\circ} \mathrm{C}$. Liberated gases were analysed on a VG Isotech SIRA II mass spectrometer, and standard corrections applied to raw $\delta^{66} \mathrm{SO}_{2}$ values to produce true $\delta^{34} \mathrm{~S}$. In addition to the conventional analysis, in situ laser combustion of sulphides was carried out on polished blocks for more detailed analyses, following the technique outlined in Wagner et al. (2002). Experimental work has shown that the laser combustion results in a small but significant fractionation of the $\delta^{34} \mathrm{~S}$ values of the resulting $\mathrm{SO}_{2}$ gas compared with the mineral $\delta^{34} \mathrm{~S}$ (e.g. Wagner et al. 2002). This fractionation has been applied to the raw $\delta^{34} \mathrm{~S}$ data, and all tabulated data are thus corrected $\left(\delta^{34} \mathrm{~S}_{\text {pyrite }}=\delta^{34} \mathrm{~S}_{\mathrm{SO} 2}\right.$ laser $+0.8 \%$; Wagner et al. 2002$) .{\mathrm{All} \mathrm{SO}_{2}}$ gases were analysed on a VG Isotech SIRA II mass spectrometer. Reproducibility for laser combustion is comparable with conventional analyses, being around $\pm 0.3 \%$ o (Wagner et al. 2002). The standards employed were the international standard NBS-123 and IAEA-S-3, and SUERC standard CP-1. These gave $\delta^{34} \mathrm{~S}$ values of $+17.1,-31$ and $-4.6 \%$, respectively, with $1 \sigma$ reproducibility better than $\pm 0.2 \%$ around the time of these analyses. Data are reported in $\delta^{34} \mathrm{~S}$ notation as per mil (\%) variations from the Vienna Canyon Diablo Troilite (V-CDT) standard.

\section{Results}

The full dataset is given in Table 1 and Fig. 3, together with mean values calculated for each group of similar 


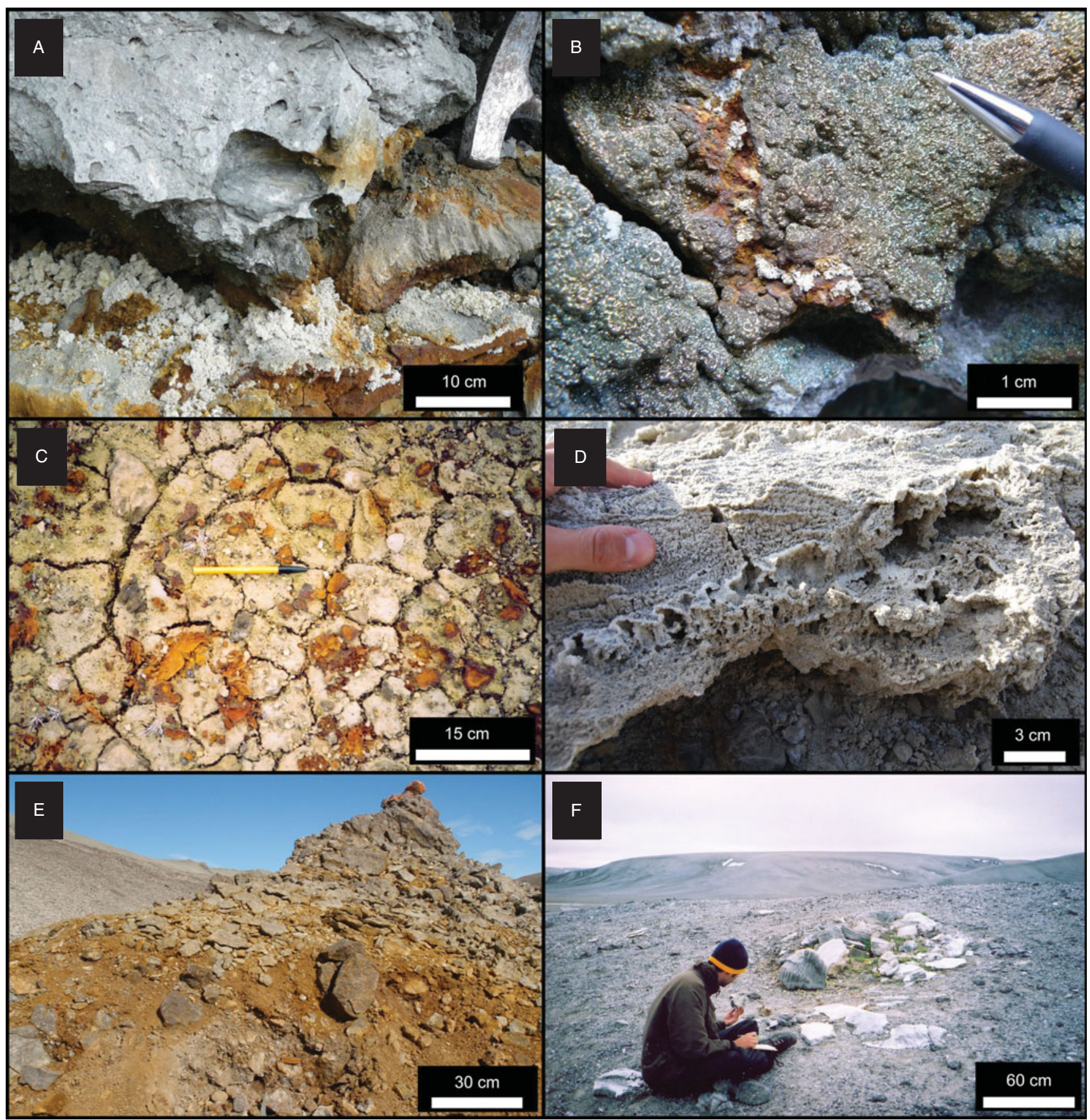

Fig. 2. Selected sampling stations along traverse through Haughton impact structure. (a) Station C, powdery sulphate on altered impact breccia, close to marcasite vein mineralization. (b) Station B, marcasite mineralization on impact breccia. (c) Station K, fragments of gypsum-iron oxide soil crust on soil surface. (d) Station A, crust of gypsum, formed on soil surface in region of gypsum bedrock. (e) Station $\mathrm{H}$, hydrothermal vent site with ferruginous weathering. (f) Station F, boulders of selenite marking intersection of selenite vein with land surface. Location for sampling stations is shown in Fig. 1.

samples. Mean values are also given in Fig. 4, which shows genetic relationships between groups. Some data are included which clearly belong to a particular group, but were collected from a locality different to those on the sampling traverse. These data conform to that from the other samples in their group and do not introduce any anomalies.
In summary, five of the seven sets of sulphate have comparable compositions in the range of +29 to $+37 \%$. The three sets of sulphide and the remaining two sets of sulphates have compositions which are isotopically lighter (lower $\delta^{34} \mathrm{~S}$ ) than the group of five sulphates, but show a wide range (Fig. 3). One of the latter two sets of sulphates yielded a bimodal dataset, the statistics for which are treated separately. 
Table 1. Sulphur isotope compositions $\left(8^{34} S, \%\right.$ CDT) of samples, Haughton impact structure

\begin{tabular}{|c|c|c|c|c|}
\hline Station & Target & Measurements & Mean & S.D \\
\hline A & $\begin{array}{l}\text { Sulphate crust } \\
\text { on bedrock }\end{array}$ & $\begin{array}{l}+25.7,+29.0,+29.3 \\
+31.2,+40.6\end{array}$ & +31.2 & 5.6 \\
\hline B & $\begin{array}{l}\text { Marcasite } \\
\text { veins }\end{array}$ & $\begin{array}{l}-36.9,-36.9,-38.7^{\mathrm{a}} \\
-40.7,-41.4,-41.6 \\
-41.6,-41.8,-42.4 \\
-43.4,-44.7\end{array}$ & -40.9 & 2.5 \\
\hline $\mathrm{C}$ & $\begin{array}{l}\text { Sulphates on } \\
\text { marcasite }\end{array}$ & $\begin{array}{r}-35.2,-26.1,-36.8 \\
-37.7,-37.9,-39.2\end{array}$ & -37.1 & 1,4 \\
\hline D & Gypsum bedrock & $\begin{array}{l}+29.1,+31.1,+31.6 \\
+31.6\end{array}$ & +30.8 & 1.2 \\
\hline $\mathrm{E}$ & $\begin{array}{l}\text { Pyrite-rich impact } \\
\text { breccia }\end{array}$ & $\begin{array}{l}-15.2,-19.3,-20.5 \\
-23.8\end{array}$ & -19.7 & 3.5 \\
\hline $\mathrm{F}$ & Selenite veins & $\begin{array}{l}+31.1,+32.0,+32.3 \\
+33.3,+33.5,+34.0\end{array}$ & +32.7 & 1.1 \\
\hline G & $\begin{array}{l}\text { Sulphate clasts in } \\
\text { impact breccia }\end{array}$ & $\begin{array}{l}+21.7,+28.4,+29.6 \\
+30.3,+30.5,+31.0\end{array}$ & +28.6 & 3.5 \\
\hline $\mathrm{H}$ & $\begin{array}{l}\text { Hydrothermal vent } \\
\text { gypsum }\end{array}$ & $\begin{array}{l}+31.8,+38.2,+39.4 \\
+40.3\end{array}$ & +37.4 & 3.8 \\
\hline $\mathrm{J}$ & Pyritic lag deposit & $\begin{array}{l}-3.4,-4.8,-6.5,-6.9 \\
-9.2,-11.7,-11.8 \\
-12.5\end{array}$ & -8.3 & 3.5 \\
\hline \multirow[t]{2}{*}{ K } & Gypsum soil crusts & $\begin{array}{l}+6.3,+6.9,+7.1,+7.8, \\
+8.0\end{array}$ & +7.2 & 0.7 \\
\hline & & $+26.5,+30.8,+32.4$ & +29.9 & 3.1 \\
\hline
\end{tabular}

${ }^{a}$ Italicized values reported in Parnell et al. (2010).

\section{Discussion}

\section{Interpretation}

Data interpretation is based on comparison between the means of the various groups of samples. Where one mean value falls outside the standard deviations of another sample, they are regarded as distinct, and evidence of isotopic fractionation.

Comparison of the mean values highlights some remarkable fractionation, particularly in the sulphides relative to most of the sulphates. Some sulphates that we know to be weathering products of sulphides also yield anomalous compositions. This is expected, as the sulphide composition should be inherited during weathering. With the benefit of an understanding of how the samples relate to each other, the isotope data can be interpreted sensibly, and this strongly implicates biological activity (Parnell et al. 2010). If we now try to make the case study more relevant to Mars, we should omit the three sets of sulphide data (B, E and J), on the assumption that sulphides would not survive oxidation at the Martian surface. Sulphates, however, are widespread on the Martian surface, so interpretation of the Haughton sulphates is a valuable test of how we could assess the sulphates on Mars. Focusing solely on the seven sets of sulphate data in the Haughton structure, it is apparent that five of the seven are comparable with each other. The two sets that are different are both surficial deposits, i.e. from the soil zone, and not primary vein minerals. They represent two out of the three soil zone precipitates, i.e. deposits formed in the top layer at the Earth's surface.

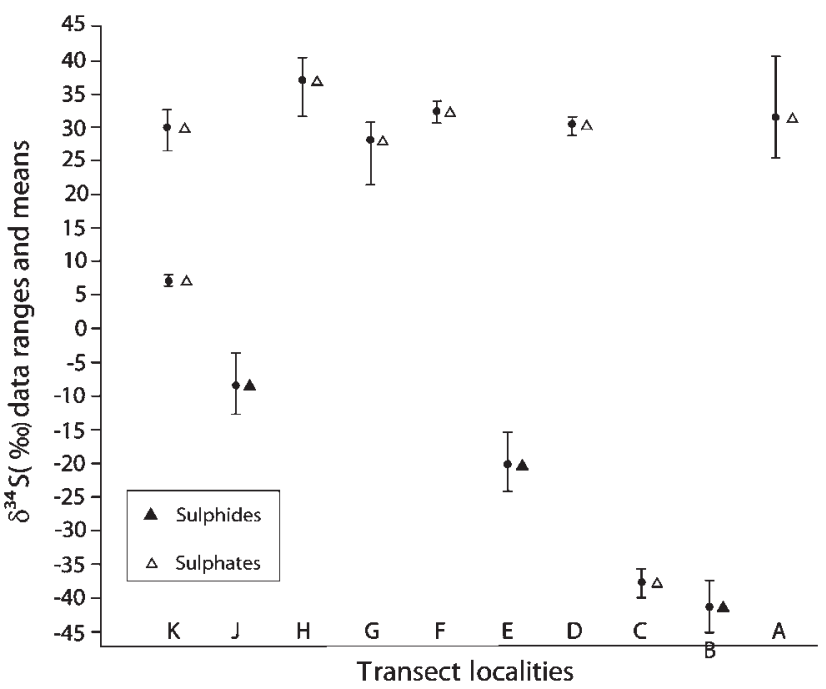

Fig. 3. Sulphur isotope data for sampling stations through Haughton impact structure (range of $\delta^{34} \mathrm{~S} \%$ CDT values, mean). Location for sampling stations is shown in Fig. 1.

If we were presented with the same set of contextual observations and isotopic data on Mars, how could we interpret it? A logical interpretation could progress as follows:

(i) The data for the pre-impact bedded gypsum (D) represent the 'baseline' composition, to which all other, younger, compositions should be compared.

(ii) The clasts in the impact breccia (G) have a similar composition, and can be inferred to be mechanically displaced and redeposited fragments of the bedded gypsum, excavated by the impact.

(iii) The vein selenite $(\mathrm{F})$ and veinrock gypsum $(\mathrm{H})$ also have similar compositions, and represent precipitation from groundwaters saturated with dissolved sulphate from the bedrock.

(iv) The three soil zone precipitates have distinct compositions. One (A) is comparable with the baseline bedded gypsum, and in fact occurs directly overlying it, so it appears to be directly remobilized from it by dissolution and reprecipitation.

(v) The two remaining soil zone precipitates are very different from the baseline and from each other. One $(\mathrm{C})$ exhibited a mean composition of $-41 \%$. The other $(\mathrm{K})$ yielded a bimodal dataset. One set has a composition comparable with the bedrock $(+30 \%)$, which we assume represents precipitation of sulphate from the regional groundwaters. The second set has a mean composition of $+7 \%$. The compositions for these two sites cannot reflect simple remobilisation, and indicate that some more complex process is responsible and deserves investigation.

The actual values for these two soil zone precipitates are isotopically light enough that on Earth they indicate biological activity, as the maximum fractionation induced by nonbiological processes is about 20\% (Machel 2001). Furthermore, the clear difference between the two indicates that, although both indicate biological activity, there were different 
4.

Modern surface

(0 Ma)

3.

Crater-fill

( 20 Ma)

2.

Impact breccia

(39 Ma)

1.

Target bedrock

(470 Ma)

\begin{tabular}{|c|c|c|c|c|}
\hline $\begin{array}{l}\text { Eroded } \\
\text { sulphate } \\
\text { lag } \\
\text { deposits }\end{array}$ & $\begin{array}{c}\text { Eroded } \\
\text { sulphide } \\
\text { lag } \\
\text { deposits }(J)\end{array}$ & $\begin{array}{l}\text { Sulphates } \\
\text { oxidized from } \\
\text { crater-fill } \\
\text { sulphides (K) }\end{array}$ & $\begin{array}{l}\text { Sulphates } \\
\text { remobilized } \\
\text { from } \\
\text { bedrock (A) }\end{array}$ & $\begin{array}{l}\text { Sulphates } \\
\text { oxidized from } \\
\text { hydrothermal } \\
\text { sulphides (C) }\end{array}$ \\
\hline
\end{tabular}
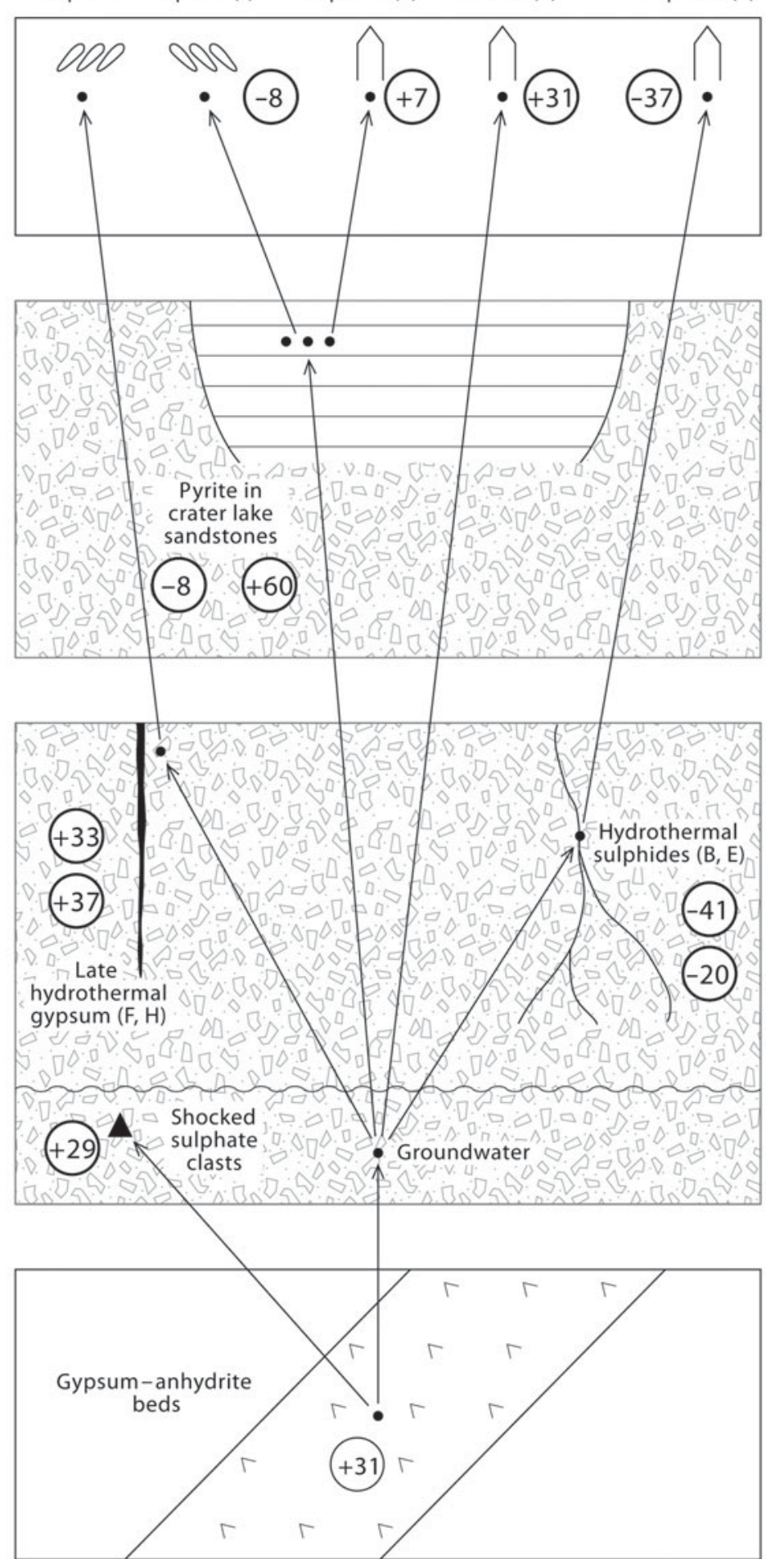

Fig. 4. Schematic relationships through time between sulphide and sulphate sample sets, with mean sulphur isotope compositions $\left(\delta^{34} \mathrm{~S} \%{ }_{0} \mathrm{CDT}\right)$ for each set.

pathways to the final product. These two sulphates exhibiting strong fractionation were derived by weathering of sulphides precipitated by microbial sulphate reduction, in one case in a marcasite-bearing hydrothermal system cutting the impact breccias (B), and the other in crater-fill sediments (J). The sulphates weathered from marcasite shows a similar composition $(-37 \% 0)$ to the marcasite $(-41 \%$ o), i.e. it has inherited the isotopic composition. The sulphate $(\mathrm{K})$ weathered from 
crater-fill sulphides is heavier $(+7 \%$ ) than the crater-fill sulphide data reported at station $\mathrm{J}$ here $(-8 \%$ ). This reflects an additional component of weathering of a paragenetically distinct, second crater-fill pyrite with very heavy composition (mean $+60 \%$ ), which was omitted from the transect described above because it would not be visible to robotic sampling. Weathering of a combination of the two crater-fill sulphides, precipitated by groundwaters rich in sulphate from surface weathering, can explain the composition of the resulting sulphate, without the need for any additional fractionation. In summary, the two soil zone sulphates carry a signature of biological activity, inherited from the sulphides from which they were weathered. In the case of the highest level of fractionation (C), detection of this anomalous composition could focus investigation, and lead to the discovery of the microbially mediated sulphides (B). If we could not observe the parent sulphides, we would still suspect biological activity, and weathering of biologically mediated sulphides would be the simplest way to explain the data. Thus, on Mars, a similar pattern of data would be of great interest.

The gypsum from the hydrothermal vent system $(\mathrm{H})$ has the heaviest mean value for sulphur $(+37 \%)$, notably heavier than the other bedrock-related datasets. A possible explanation for this is that it is balanced by isotopically light sulphide elsewhere in the hydrothermal system. A single pyrite sample from this locality has a composition of $-8.4 \%$ (Parnell et al. 2010), which is consistent with isotopic fractionation between sulphide and sulphate due to microbial sulphate reduction.

There is no doubt that the sulphur in the various sulphide and sulphate samples can be traced ultimately back to the preimpact bedrock. It is possible that the impactor contained sulphur, as many meteorites contain sulphides (Kaplan \& Hulston 1966), but the impactor was completely vaporized and most of the resulting gases would have escaped the crater. More pertinently, the hydrothermal sulphides occur in impact breccias whose sulphur content is dominated by comminuted bedrock gypsum, and sulphate melts derived from the gypsum (Osinski \& Spray 2003). That sulphur would exceed any traces of meteoritic sulphur by several orders of magnitude. Furthermore, sulphide precipitation was a relatively low $\left(<100^{\circ} \mathrm{C}\right)$ temperature event (Parnell et al. 2010), implying derivation of the sulphur from the bedrock through the regional groundwaters, which are sulphate-rich (Lim \& Douglas 2003).

\section{Potential application to Mars}

The widespread occurrence of sulphate minerals on Mars (see Introduction) shows that material is available for sampling for sulphur isotope analysis, hence the development of appropriate technology (Christensen et al. 2007; Franz et al. 2007). If there is life on Mars today, the microbial sulphate reduction which is the basis of the isotopic fractionation on Earth is conceivable. Both redox reactions involving reduction and oxidation of sulphur species are theoretically capable of providing the energy to support a significant biomass on the current Martian surface (Tierney \& Jakosky 2008), and sulphate reducers can tolerate the saline solutions that allow liquid to persist at low surface temperatures (Marnocha et al. 2010). Some of the bedded sulphates on Mars date back to $3.5 \mathrm{Ga}$ when the surface was warmer and wetter than now. At that time, conditions were much more closely comparable with those on Earth, where we assume that biogenic sulphate reduction was possible (Canfield 2004). If life did evolve on Mars, this is possibly the most likely period for it to arise, and evidence could be stored in the bedded sulphates. However, it seems that there has been repeated dissolution and reprecipitation of sulphates through the geological history of Mars (King \& McLennan 2010), so there would have been opportunities for involvement and entrapment of later-evolving microbial communities.

The fractionation between sulphate and sulphide induced by microbial activity in the Haughton impact structure is up to 70\%o (Parnell et al. 2010). These high levels of fractionation reflect the evolution of disproportionation, which involves a combination of sulphate reduction and sulphide oxidation (Johnston et al. 2007). Less evolved microbial activity in the late Archean and early Proterozoic on Earth caused fractionation by sulphate reduction alone, typically $20-25$ per mil, much less than today (Strauss 1997; Canfield 2004). Earlier in the Archean, when sulphate levels in the ocean were very low and less fractionation was possible due to low sulphate availability, the fractionation may have been a few per mil. On Mars, any microbial activity that had evolved to instigate sulphate reduction is likely to have caused isotope fractionation. The level of fractionation would reflect the concentration of sulphate available (i.e. more fractionation is possible with increased sulphate concentrations), which on Mars was high, and the time available for evolution to occur, which was probably much more limited than on Earth. On Earth, it also reflects the nature of the substrate and degree of substrate oxidation, and is variable between different microbes (Habicht \& Canfield 1997; Detmers et al. 2001). However, even greatly reduced levels of isotope fractionation on Mars, for example of the order of $5-10 \%$, would indicate processing of sulphur species by some means that could include biological activity. Any record of strongly positive, or strongly negative, sulphur isotope compositions, which in terrestrial samples indicate biological activity, would be of even greater interest.

The known Martian meteorites have yielded sulphur isotope compositions with a range of $\delta^{34} \mathrm{~S}$ values from -6 to $+8 \%$ (Shearer et al. 1996; Greenwood et al. 1997, 2000a, b; Farquhar et al. 2000, 2007), although individual meteorites exhibit ranges of just a few parts per mil. The additional measurement of rare sulphur isotopes ${ }^{33} \mathrm{~S}$ and ${ }^{36} \mathrm{~S}$ has indicated that photolysis in the atmosphere can cause sulphur isotopic fractionation, resulting in some limited variation in $\delta^{34} \mathrm{~S}$ values (Farquhar et al. 2000, 2007). If large variations in $\delta^{34} \mathrm{~S}$ were measured on the Martian surface, it would be very helpful to also measure ${ }^{33} \mathrm{~S}$ in order to discriminate whether atmospheric processes may have contributed to the fractionation, or alternatively did not and so strengthen the possibility of a biological role (Farquhar et al. 2000). The instrumentation proposed by Christensen et al. (2007) suggests that such measurement could be feasible in due course. 


\section{Conclusions}

The analogue study of sulphur isotope composition of surface sulphates in a Mars analogue site, the Haughton impact structure, has demonstrated that this is a valuable and viable approach to apply to the surface sulphates that we know occur on Mars. Specifically:

(i) Different populations of sulphates, reflecting different histories of sulphur cycling, could be distinguished.

(ii) Analysis of sulphates weathered from sulphides allows us to infer compositions of the sulphides, even where the sulphides cannot be directly sampled because of the depth of chemical weathering.

(iii) Where the parent sulphide was precipitated by microbial sulphate reduction, this evidence for life is preserved in the composition of the sulphate.

(iv) Anomalous compositions could be identified during robotic exploration, and, although no unique interpretation of such anomalies is possible, they could contribute to decisions about where to focus other types of analysis.

\section{Acknowledgments}

We are grateful to John Still, Barry Fulton, Colin Taylor, Alison Sandison and Alison McDonald for skilled technical help. This work was conducted in part under the auspices of the Haughton-Mars Project with support from NASA, Mars Institute, SETI Institute and the Canadian Space Agency. The arctic communities of Grise Fiord and Resolute Bay are also thanked. We are grateful to four anonymous reviewers who commented on earlier versions of the manuscript.

\section{Author disclosure statement}

No competing financial interests exist.

\section{References}

Aubrey, A., Cleaves, H.J., Chalmers, J.H., Skelley, A.M., Mathies, R.A., Grunthaner, F.J., Ehrenfreund, P. \& Bada, J.L. (2006). Sulfate minerals and organic compounds on Mars. Geology 34, 357-360.

Barlow, N.G. (1990). Constraints on early events in Martian history as derived from the cratering record. J. Geophys. Res. 95, 14191-14203.

Brunner, B. \& Bernasconi, S.M. (2005). A revised isotope fractionation model for dissimilatory sulfate reduction in sulfate reducing bacteria. Geochim. Cosmochim. Acta 69, 4759-4771.

Burns, R.G. \& Fisher, D.S. (1990). Iron-sulfur mineralogy on Mars: magmatic evolution and chemical weathering products. J. Geophys. Res. 95, B14415-B14421.

Burns, R.G. \& Fisher, D.S. (1993). Rates of oxidative weathering on the surface of Mars. J. Geophys. Res. 98, E3365-E3372.

Canfield, D.E. (2004). The evolution of the Earth surface sulfur reservoir. Am. J. Sci. 304, 839-861.

Chevrier, V., Rochette, P., Mathé, P.-E. \& Grauby, O. (2004). Weathering of iron-rich phases in simulated Martian atmospheres. Geology 32, 1033-1036.

Christensen, L.E., Brunner, B., Truong, K.N., Mielke, R.E., Webster, C.R. \& Coleman, M. (2007). Measurement of sulfur isotope compositions by tunable laser spectroscopy of $\mathrm{SO}_{2}$. Anal. Chem. 79, 9261-9268.

Cid, A. \& Casanova, I. (2001). Sulphates in Martian soils: a clear exobiological target. In Proceedings of the First European Workshop on
Exo-Astrbiology (European Space Agency Special Publication 496), pp. 201-202. European Space Agency, Noordwijk.

Coleman, M.L. \& Moore, M.P. (1978). Direct reduction of sulphates to sulphur dioxide for isotopic analysis. Anal. Chem. 28, 199-260.

Crucian, B., Lee, P., Stowe, R., Jones, J., Effenhauser, R., Widen, R. \& Sams, C. (2007). Immune system changes during simulated planetary exploration on Devon Island, High Arctic. BMC Immunology 8, 7. doi: 10.1186/1471-2172-8-7.

Detmers, J., Bruchert, V., Habicht, K. \& Kuever, J. (2001). Diversity of sulfur isotope fractionations by sulfate-reducing prokaryotes. Appl. Environ. Microbiol. 67, 888-894.

Farquhar, J., Kim, S.-T. \& Masterson, A. (2007). Implications from sulfur isotopes of the Nakhla meteorite for the origin of sulfate on Mars. Earth Planet. Sci. Lett. 264, 1-8.

Farquhar, J., Savarino, J., Jackson, T.L. \& Thiemens, M.H. (2000). Evidence of atmospheric sulphur in the Martian regolith from sulphur isotopes in meteorites. Nature 404, 50-52.

Franz, H.B., Mahaffy, P.R. \& Farquhar, J. (2007). Preliminary estimate of sulfur isotope ratio precision expected with the sample analysis at Mars (SAM) instrument suite of the 2009 Mars Science Laboratory. In Lunar and Planetary Science Conference XXXVIII, abstract 1874.

Franz, H.B., Mahaffy, P.R., Kasprzak, W., Lyness, E. \& Raaen, E. (2011). Measuring sulfur isotope ratios from solid samples with the Sample Analysis at Mars instrument and the effects of dead time corrections. In 42nd Lunar and Planetary Science Conference, abstract 2800.

Furgale, P., Barfoot, T. \& Ghafoor, N. (2010). Rover-based surface and subsurface modelling for planetary exploration. Field and Service Robotics 7. Springer Tracts Adv. Robot. 62, 499-508.

Gaillard, F. \& Scaillet, B. (2009). The sulfur content of volcanic gases on Mars. Earth Planet. Sci. Lett. 279, 34- 43.

Gendrin, A. et al. (2005). Sulfates in Martian layered terrains: the OMEGA/ Mars Express view. Science 307, 1587-1591.

Glynn, S., Mills, R.A., Palmer, M.R., Pancost, R.D., Severmann, S. \& Boyce, A.J. (2006). The role of prokaryotes in supergene alteration of submarine hydrothermal sulfides. Earth Planet. Sci. Lett. 244, $170-185$.

Greenwood, J.P., Mojzsis, S.J. \& Coath, C.D. (2000a). Sulfur isotopic compositions of individual sulfides in Martian meteorites ALH84001 and Nakhla: implications for crust-regolith exchange on Mars. Earth Planet. Sci. Lett. 184, 23-35.

Greenwood, J.P., Riciputi, L.R. \& McSween, H.Y. (1997). Sulfide isotopic compositions in shergottites and ALH84001, and possible implications for life on Mars. Geochim. Cosmochim. Acta 61, 4449-4453.

Greenwood, J.P., Riciputi, L.R., McSween, H.Y. \& Taylor, L.A. (2000b). Modified sulpfur isotopic compositions of sulfides in the nakhlites and Chassigny. Geochim. Cosmochim. Acta 64, 1121-1131.

Habicht, K.S. \& Canfield, D.E. (1997). Sulfur isotope fractionation during bacterial sulfate reduction in organic-rich sediments. Geochim. Cosmochim. Acta 24, 5351-5361.

Hickey, L.J., Johnson, K.R. \& Dawson, M.R. (1988). The stratigraphy, sedimentology, and fossils of the Haughton formation: a post-impact crater-fill, Devon Island, N.W.T., Canada. Meteoritics 23, 221-231.

Johnson, S.S., Mischna, M.A., Grove, T.L. \& Zuber, M.T. (2008). Sulfurinduced greenhouse warming on early Mars. J. Geophys. Res. 113, doi: 10.1029/2007JE002962.

Johnston, D.T., Farquhar, J. \& Canfield, D.E. (2007). Sulfur isotope insights into microbial sulphate reduction: when microbes meet models. Geochim. Cosmochim. Acta 71, 3929-3947.

Johnston, D.T., Farquhar, J., Habicht, K.S. \& Canfield, D.E. (2008). Sulphur isotopes and the search for life: strategies for identifying sulphur metabolisms in the rock record and beyond. Geobiology 6, 425-435.

Kaplan, I.R. \& Hulston, J.R. (1966). The isotopic abundance and content of sulfur in meteorites. Geochim. Cosmochim. Acta 30, 479-496.

King, P.L., Lescinsky, D.T. \& Nesbitt, H.W. (2004). The composition and evolution of primordial solutions on Mars, with applications to other planetary bodies. Geochim. Cosmochim. Acta 68, 4993-5008.

King, P.L. \& McLennan, S.M. (2010). Sulfur on Mars. Elements 6, $107-112$. 
Kounaves, S.P. et al. (2010). Confirmation of soluble sulfate at the Phoenix landing site: implications for Martian geochemistry and habitability. In 41st Lunar and Planetary Science Conference, abstract 2199.

Lane, M.D., Bishop, J.L., Dyar, M.D., King, P.L., Parente, M. \& Hyde, B.C. (2008). Mineralogy of the Paso Robles soils on Mars. Am. Mineral. 93, 728-739.

Lefticariu, L., Pratt, L.M. \& Ripley, E.M. (2006). Mineralogic and sulfur isotopic effects accompanying oxidation of pyrite in millimolar solutions of hydrogen perozide at temperatures from 4 to $150^{\circ} \mathrm{C}$. Geochim. Cosmochim. Acta 70, 4889-4905.

Lim, D.S.S. \& Douglas, M.S.V. (2003). Limnological characteristics of 22 lakes and ponds in the Haughton Crater region of Devon Island, Nunavut, Canadian High Arctic. Arctic, Antarctic Alpine Res. 35, 509-519.

Lorand, J.-P., Chevrier, V. \& Sautter, V. (2005). Sulfide mineralogy and redox conditions in some shergottites. Meteorit. Planet. Sci. (USA) 40 , 1257-1272.

Machel, H.G. (2001). Bacterial and thermochemical sulfate reduction in diagenetic settings - old and new insights. Sediment. Geol. 140, 143-175.

Marnocha, C.L., Chevrier, V.F. \& Ivey, D.M. (2010). Sulfate-reducing bacteria as a model for life in the martian subsurface. In 41st Lunar and Planetary Science Conference, abstract 1536.

McLennan, S.M. et al. (2005). Provenance and diagenesis of the evaporitebearing Burns formation, Meridiani Planum, Mars. Earth Planet. Sci. Lett. 240, 95-121.

Newsom, H.E. et al. (2009). Simulated rover field test at the Haughton-Mars project impact crater field station. In 40th Lunar and Planetary Science Conference, abstract 1446.

Osinski, G.R. \& Lee, P. (2005). Intra-crater sedimentary deposits at the Haughton impact structure, Devon Island, Canadian High Arctic. Meteorit. Planet. Sci. 40, 1887-1899.

Osinski, G.R., Lee, P., Parnell, J., Spray, J.G. \& Baron, M. (2005a). A case study of impact-induced hydrothermal activity: the Haughton impact structure, Devon Island, Canadian High Arctic. Meteorit. Planet. Sci. 40 , 1859-1877.

Osinski, G.R., Lee, P., Spray, J.G., Parnell, J., Lim, D.S.S., Bunch, T.E., Cockell, C.S. \& Glass, B. (2005b). Geological overview and cratering model for the Haughton impact structure, Devon Island, Canadian High Arctic. Meteorit. Planet. Sci. 40, 1759-1776.

Osinski, G.R. \& Spray, J.G. (2003). Evidence for the shock melting of sulfates from the Haughton impact structure, Arctic Canada. Earth Planet. Sci. Lett. 215, 357-370.
Osinski, G.R., Spray, J.G. \& Lee, P. (2001). Impact-induced hydrothermal activity within the Haughton impact structure, Arctic Canada: generation of a transient, warm, wet oasis. Meteorit. Planet. Sci. 36, 731-745.

Parnell, J. et al. (2010). Sulfur isotope signatures for rapid colonization of an impact crater by thermophilic microbes. Geology 38, 271-274.

Parnell, J., Lee, P., Cockell, C.S. \& Osinski, G.R. (2004). Microbial colonization in impact-generated hydrothermal sulphate deposits, Haughton impact structure, and implications for sulphates on Mars. Int. J. Astrobiol. 3, 247-256.

Righter, K., Pando, K. \& Danielson, L.R. (2009). Experimental evidence for sulfur-rich martian magmas: implications for volcanism and surficial sulfur sources. Earth Planet. Sci. Lett. 288, 235-243.

Robinson, B.W. \& Kusakabe, M. (1975). Quantitative preparation of sulfur dioxide for ${ }^{34} \mathrm{~S} /{ }^{32} \mathrm{~S}$ analyses from sulphides by combustion with cuprous oxide. Anal. Chem. 47, 1179-1181.

Rothschild, L.J. (1990). Earth analogs for Martian life. Microbes in evaporites, anew model system for life on Mars. Icarus 88, 246-260.

Shearer, C.K., Layne, G.D., Papike, J.J. \& Spilde, M.N. (1996). Sulfur isotopic systematic in alteration assemblages in Martian meteorite Allan Hills 84001. Geochim. Cosmochim. Acta 60, 2921-2926.

Sherlock, S.C., Kelley, S.P., Parnell, J., Green, P., Lee, P., Osinski, G.R. \& Cockell, C.S. (2005). Re-evaluating the age of the Haughton impact event. Meteorit. Planet. Sci. 40, 1777-1787.

Space Studies Board (2007). An Astrobiology Strategy for the Exploration of Mars. National Academies Press, Washington, DC

Strauss, H. (1997). The isotopic composition of sedimentary sulfur through time. Palaeogeogr. Palaeoclimatol. Palaeoecol. 132, 97-118.

Tierney, L.L. \& Jakosky, B.M. (2008). Assessing the habitability of Meridiani Planum, Mars, based on thermodynamic energy requirements. In Lunar and Planetary Science Conference XXXIX, abstract 1396.

Toran, L. \& Harris, R.F. (1989). Interpretation of sulfur and oxygen isotopes in biological and abiological sulfide oxidation. Geochim. Cosmochim. Acta 53, 2341-2248.

van Zuilen, M. (2008). Stable isotope ratios as a biomarker on Mars. Space Sci. Rev. 135, 221-232.

Wagner, T., Boyce, A.J. \& Fallick, A.E. (2002). Laser combustion analysis of $\delta^{34} \mathrm{~S}$ of sulfosalt minerals: determination of the fractionation systematics and some crystal-chemical considerations. Geochim. Cosmochim. Acta 66, 2855-2863.

Yen, A.S. et al. (2008). Hydrothermal processes at Gusev Crater: an evaluation of Paso Robles class soils. J. Geophys. Res. 113, doi: 10.1029/ 2007JE002978. 